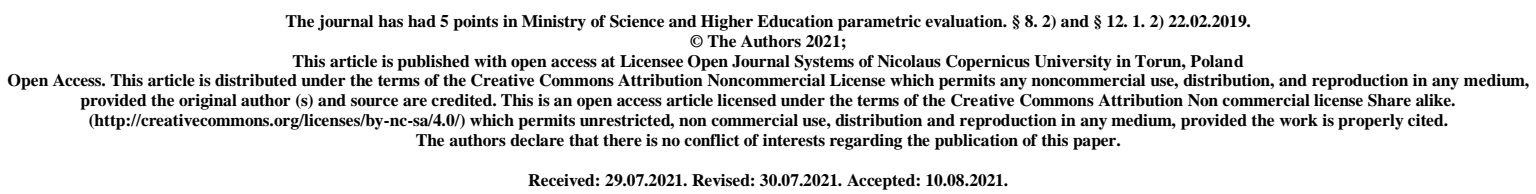

\title{
Juvenile Idiopathic Arthritis
}

\author{
Aleksandra Strońska ${ }^{1}$, Konrad Grzeszczak $^{2}$, Karolina Rogulska $^{3}$ \\ ${ }^{1}$ Department of Pharmacognosy and Natural Medicines, Pomeranian Medical University in \\ Szczecin, Powstańców Wlkp. 72, 70-111 Szczecin, Poland \\ ${ }^{2}$ Department of Biology and Medical Parasitology, Pomeranian Medical University in \\ Szczecin, Powstańców Wielkopolskich 72, 70-111 Szczecin, Poland \\ ${ }^{3}$ Department of Microbiology, Immunology and Laboratory Medicine, Pomeranian Medical \\ University, Powstańców Wlkp. 72, 70-111 Szczecin, Poland.
}

\begin{abstract}
Juvenile idiopathic arthritis (JIA) is the most common chronic inflammatory rheumatic disease in childhood. It is a heterogeneous group of diseases characterized by arthritis, extraarticular features including uveitis and, in some cases, laboratory markers. The course of the disease, therapeutic management and prognosis vary depending on the primary JIA category. Recent advances in treatment, especially the use of biological agents, have significantly reduced the incidence of JIA. Current treatment approaches emphasize aggressive early treatment to delay disease progression and improve outcomes. However, the disease can remain active into adulthood and constant careful monitoring is still needed.
\end{abstract}

Keywords: Juvenile idiopathic; physiotherapy 


\section{Introduction}

Juvenile idiopathic arthritis (JIA) is the most common chronic, immune-mediated connective tissue disease of the developmental age. The essence of the disease is a chronic inflammatory process that damages the articular cartilage, bone epiphyses and is responsible for extra-articular symptoms and systemic complications. The disease can occur at any stage of developmental age, and a very large number of symptoms create problems in the diagnosis of the disease, especially in the initial stage of its development [1]. According to the International League of Associations for Rheumatology (ILAR), the term juvenile idiopathic arthritis refers to a heterogeneous set of arthritis of unknown etiology lasting at least 6 weeks and starting before the age of 16 .

The diagnosis of JIA in patients is made only after the exclusion of diseases from the exclusion list, which includes infectious, reactive, allergic and toxic arthritis, proliferative diseases, arthropathies in blood diseases and metabolic diseases, systemic non-inflammatory diseases of connective tissue, arthropathies in immunological diseases, psychogenic rheumatism and fibromyalgia and other inflammatory connective tissue diseases [2]

The current ILAR classification criteria divide JIA into 6 mutually exclusive categories defined by the number of joints involved, the presence or absence of extra-articular symptoms, and the presence or absence of additional markers, including rheumatoid factor (RF) and HLA- B27 (Human B27 leukocyte antigen) [3]

All forms of JIA are associated with reduced health-related quality of life and the risk of permanent joint damage, and the disease may persist into adulthood, resulting in significant ongoing morbidity and reduced quality of life [4-12]

\section{Etiology}

The etiopathogenesis of arthritis is not fully understood. Three hypotheses of the causes of juvenile idiopathic inflammation were put forward: genetic predisposition (a major role is attributed to HLA DR (MHC class II cell surface receptor, encoded by the human leukocyte antigen complex) and HLA DQ (human leukocyte antigen-DQ), the influence of environmental factors (most likely various types of infections, physical and mental injuries) leading to numerous immunological disorders The results of immunogenetic disorders are not clear, however the exact cause of inflammation is unknown and therefore the number of patients suffering from atypical arthritis and the evolution of one disease continues to increase. in the second form of arthritis, there is a need to find new parameters allowing the classification of the patient to the appropriate clinical group and appropriate treatment [13].

\section{Classification and criteria for the diagnosis of clinical forms of JIA}

The International League of Associations for Rheumatologys (ILAR) has classified 6 different clinical forms of JIA:

- JIA with polyarticular onset;

- JIA with a sparse articular beginning;

- JIA with generalized onset;

- psoriatic arthritis;

- arthritis with associated tendonitis; 
- Unclassified JIA characters.

JIA subtypes have been classified based on the following factors: child's age, rheumatoid factor RF, and number of inflamed joints. Determining the type of juvenile idiopathic arthritis as early as possible helps to assess the rate of disease progression [14]

JIA with polyarticular onset is divided into two groups: with the presence of the rheumatoid factor RF and without the presence of the rheumatoid factor. JIA in the absence of $\mathrm{RF}$ is characterized by acute or subacute arthritis of at least 5 joints. The most common symptoms of this inflammation are symmetrical swelling of the knee, wrist and ankle joints. Patients also suffer from morning stiffness combined with pain and a problem with dilation of the mandible $[14,15]$. JIA with rheumatoid factor RF is characterized by symptoms similar to RA in adults. The occurrence of subcutaneous nodules is observed, the inflammation process affects the small fingers of the joints of the feet and hands. All these negative factors lead to irreversible degenerative changes in the joints $[14,16]$

JIA with the initial involvement of a small number of joints - otherwise oligoarthritis accounts for as much as $50 \%$ of children suffering from this disease. It is characterized by persistent, chronic inflammation of one to four joints combined with the exclusion of another disease or form of JIA. Arthritis is often single-joint, $80 \%$ of it is the knee, although there are also elbows, wrists and ankles. The examination shows pain with active movements, increased tissue warmth and decreased mobility in the joint. Since arthritis is often asymmetric, bones may develop at different rates, causing uneven growth in the lower limbs $[15,16]$.

Generalized JIA is inflammation of at least one joint, accompanied by fever for at least 2 weeks, and at least one symptom such as enlarged liver, spleen, rash erythematous, and enlarged lymph nodes. Arthritis affects both large and small joints. Usually symptoms become apparent after 3 months. Often, with the development of the disease, it turns into a polyarticular form.

In psoriatic arthritis, the disease presents with symptoms of arthritis and psoriasis, as well as at least two of the following symptoms: inflammation of the fingers, psoriasis in a 1st degree relative, separation of the nail plates from the placenta. It is estimated that $5-7 \%$ of children suffering from JIA suffer from this form of the disease. The course of the disease is not uniform, and studies show that in 50\% of patients, arthritis first developed, and then skin lesions appeared [3].

JIA with associated tendon attachment inflammation is characterized by precisely attaching tendonitis and at least two of the following criteria:

- onset of the disease in a child over 8 years of age;

- the presence of HLA B27 or the presence of this gene in the family;

- uveitis;

- ankylosing spondylitis, reactive arthritis;

- pain in the sacroiliac joint or tenderness in the spine.

Patients with enthesitis have a painful stiffness that can occur even in the absence of true arthritis. 
The most common location of tendon attachment inflammation is the Achilles tendon and the attachment of the quadriceps to the patella. The prognosis is very good, long-lasting remission in about three quarters of patients is maintained during puberty [17].

\section{Rehabilitation proceedings}

Comprehensive rehabilitation is aimed at accelerating natural regeneration and reducing the physical effects of the disease. In JIA, the therapy is based on the analgesic and muscle-relaxing effects. Exercises to help maintain adequate mobility in the affected joints are also important. The main principles of rehabilitation in JIA are to avoid overloading the joints and to select the appropriate exercises according to the form of JIA.

Kinesiotherapy is the most important element of rehabilitation in JIA. Increases the range of movements in the joints, reduces the size of muscle atrophy. A properly selected rehabilitation plan is strictly dependent on the activity of the disease [18].

During acute arthritis, activities are performed that lead to the relaxation of the fasciamuscular tense tissues. Passive exercises contributing to better nutrition and blood supply to the articular cartilage are also recommended during acute arthritis. However, when performing the above-mentioned activities, particular caution should be exercised because arthritis may be exacerbated due to overload [17, 19].

During disease remission, an extended range of acute therapy is performed. During periods of remission, an extended range of acute therapy is performed. Additionally, redressive lifts are performed to improve the range of motion in the joints and to reduce the contracture of soft tissues. Before applying the extract, it is necessary to relax the treatment area with massage or physical therapy [20,21].

Kinesiotaping is a modern method supporting the therapy of children with JIA. Kinesiotaping techniques support natural healing processes based on proper human movement. The creator of kinesiotaping, Kenzo Kase, distinguished six application techniques: mechanical, spatial, fascial, ligamentous, functional and lymphatic. Depending on the technique used, a physiotherapist is able to improve the function of muscles and joints, normalize muscle tension or improve the functioning of the lymphatic system, helping to reduce swelling. Thanks to the painless application and the variety of colors of the patches, children are eager to undergo this form of therapy. Kinesiotaping is an effective method in the comprehensive rehabilitation of children with JIA [22]. Properly selected and conducted kinesiotherapy is able to generate new movement patterns that cause the return of lost functions in the joint affected by the disease [21].

Physical therapy should be carried out in parallel with kinesiotherapeutic and pharmacological treatment. Thanks to the use of treatments, you can get an analgesic, antiinflammatory and muscle-reducing effect. It is recommended that any treatments relaxing tense muscles and reducing pain should be performed before kinesiotherapy. People suffering from rheumatic diseases tolerate cryotherapy treatments well. Their essence consists in reflex vasoconstriction with delayed, prolonged vasodilatation caused by a significant decrease in tissue temperature. Most often, local cryotherapy is used for this purpose, affecting the hyperemia of the subcutaneous tissue and skin. The treatment reduces the release of inflammatory mediators and pain mediators, which results in the reduction of pain and muscle tension $[16,23]$. 


\section{Treatment}

After the diagnosis of JIA is made, immediate drug treatment modifying the course of JIA should be started. Until diagnosis is made, patients are treated symptomatically with nonsteroidal anti-inflammatory drugs that reduce pain and inflammation.

The treatment strategy for JIA should take into account the type of onset and course of the disease, the presence of poor prognosis factors, and complications that may occur in the developmental age. Determining the therapy should take into account the individual course of the patient's disease, and the treatment should be comprehensive, taking into account the participation of specialists from many fields.

So far, disease-modifying and immunosuppressive drugs have been widely used: methotrexate (MTX), sulfasalazine (SSA), antimalarial drugs (Arechina, Hydroxychloroquine), cyclosporine (CsA), Imuran, non-steroidal anti-inflammatory drugs (NSAIDs) and glucocorticosteroids (GCs) used in both in the form of intravenous infusions, orally and intraarticularly [24]. To date, there is no fully effective treatment of JIA, so there is a need to search for drugs or drug combinations with a greater therapeutic effect [25].

In patients with high disease activity, when there is no response to the basic treatment used, biological therapy should be introduced. Biological JIA treatment is a therapeutic alternative in the event of ineffectiveness of treatment with classic disease-modifying drugs and immunosuppressants. In addition to tumor necrosis factor (TNF) blockers widely used in various clinical forms of JIA, we have other biological drugs at our disposal, including interleukin 1 (anti-IL-1) blockers, anti-IL-6 blockers, abatacept (anti-IL-1) blockers, activation of $\mathrm{T}$ lymphocytes) and rituximab (anti-CD20 monoclonal antibody). Currently, there are new molecules in clinical trials that can play a significant role in the treatment of JIA, ustekinumab, an IL-23 blocker and tofacitinib (an oral drug), a Janus kinase inhibitor (JAK, Janus kinases) and a transcriptional activator blocker (STAT) [26]. 


\section{References}

1. Smolewska E, Żuber Z. Aktualne cele, możliwości i perspektywy leczenia młodzieńczego idiopatycznego zapalenia stawów w Polsce i na świecie. Forum Reumatol. 2016;2:14-20. www.fr.viamedica.pl. Accessed 27 Apr 2021.

2. Rutkowska-Sak L, Tuszkiewicz-Misztal E, Brózik H, Niedziela M, Żuber Z, Tłustochowicz W, et al. Stanowisko Zespołu Ekspertów ds. Reumatologii Dziecięcej przy Konsultancie Krajowym w Dziedzinie Reumatologii dotyczące terapii biologicznej w leczeniu młodzieńczego idiopatycznego zapalenia stawów. Reumatologia. 2009.

3. Petty RE, Southwood TR, Manners P, Baum J, Glass DN, Goldenberg J, et al. International League of Associations for Rheumatology classification of juvenile idiopathic arthritis: second revision, Edmonton, 2001. J Rheumatol. 2004;31:390 LP - 392. http://www.jrheum.org/content/31/2/390.abstract.

4. Gutiérrez-Suárez R, Pistorio A, Cespedes Cruz A, Norambuena X, Flato B, Rumba I, et al. Health-related quality of life of patients with juvenile idiopathic arthritis coming from 3 different geographic areas. The PRINTO multinational quality of life cohort study. Rheumatology. 2007;46:314-20. doi:10.1093/rheumatology/kel218.

5. Seid M, Opipari L, Huang BIN, Brunner HI, Lovell DJ. Disease control and health-related quality of life in juvenile idiopathic arthritis. Arthritis Care Res. 2009;61:393-9.

doi:10.1002/art.24477.

6. Minden K, Niewerth M, Listing J, Biedermann T, Bollow M, Schöntube M, et al. Longterm outcome in patients with juvenile idiopathic arthritis. Arthritis Rheum. 2002;46:2392401. doi:10.1002/art.10444.

7. Oen K, Malleson PN, Cabral DA, Rosenberg AM, Petty RE, Cheang M. Disease course and outcome of juvenile rheumatoid arthritis in a multicenter cohort. J Rheumatol. 2002;29. 8. Zak M, Pedersen FK. Juvenile chronic arthritis into adulthood: A long-term follow-up study. Rheumatology. 2000;39:198-204. doi:10.1093/rheumatology/39.2.198.

9. Schanberg LE, Anthony KK, Gil KM, Maurin EC. Daily pain and symptoms in children with polyarticular arthritis. Arthritis Rheum. 2003;48:1390-7. doi:10.1002/art.10986.

10. Schanberg LE, Gil KM, Anthony KK, Yow E, Rochon J. Pain, stiffness, and fatigue in juvenile polyarticular arthritis: Contemporaneous stressful events and mood as predictors. Arthritis Rheum. 2005;52:1196-204. doi:10.1002/art.20952.

11. Ringold S, Wallace CA, Rivara FP. Health-related quality of life, physical function, fatigue, and disease activity in children with established polyarticular juvenile idiopathic arthritis. J Rheumatol. 2009;36:1330-6. doi:10.3899/jrheum.081028.

12. Ringold S, Ward TM, Wallace CA. Disease activity and fatigue in juvenile idiopathic arthritis. Arthritis Care Res (Hoboken). 2013;65:391-7. doi:10.1002/acr.21801.

13. Mazur-Zielińska H, Sufleta A, Zieliński M, Hajdrowska B. Przeciwciała przeciwko cyklicznemu cytrulinowanemu peptydowi (anty-CCP) u dzieci z młodzieńczym idiopatycznym zapaleniem stawów. Pediatr Pol. 2012;87:246-8.

14. Rutkowska-Sak L, Gietka P, Wierzbowska M, Gazda A, Kołodziejczyk B, Kwiatkowska $\mathrm{M}$, et al. Reumatologia wieku rozwojowego Rheumatic diseases in the age of the child.

Termedia; 2012.

15. Berkun Y, Padeh S. Environmental factors and the geoepidemiology of juvenile idiopathic arthritis. Autoimmun Rev. 2010;9:A319-24. doi:10.1016/j.autrev.2009.11.018. 
16. Gietka P, Rutkowska-Sak L, Lisowska B. Zapalenie mięsni w przebiegu układowej postaci młodzieńczego idiopatycznego zapalenia stawów. Reumatologia. 2014;52:142-5. 17. Księżopolska-Orłowska K. Postępowanie rehabilitacyjne w reumatologii Rehabilitation procedures in rheumatology. Termedia; 2012.

18. Tuszkiewicz-Misztal E. OE. Postępy w reumatologii dziecięcej w 2015 roku - Postępy w pediatrii - Artykuły i wytyczne - Pediatria - Medycyna Praktyczna dla lekarzy. Med Prakt Pediatr. 2015. https://www.mp.pl/pediatria/artykuly-wytyczne/postepy/146925,postepy-wreumatologii-dzieciecej-w-2015-roku. Accessed 27 Apr 2021.

19. Zuk B, Księzopolska-Orłowska K. Ochrona stawów w reumatoidalnym zapaleniu stawów. Zaopatrzenie ortopedyczne. Reumatologia. 2009;47:241-8.

20. Zuk B. Improving knee joint in children 2-3 years old with juvenile idiopathic arthritis Usprawnianie stawu kolanowego u dzieci 2 - 3-letnich z młodzieńczym idiopatycznym zapaleniem stawów. 2019; January 2008.

21. Agnieszka W, Zajkiewicz K. Assessment of Balance and Motor Coordination in Children with Juvenile Idiopathic Arthritis. Przegląd Med Uniw Rzesz i Nar Inst Leków w Warszawie. 2014;1:25-6.

22. Żuk B, Księżopolska-Orłowska K. Przydatność metody Kinesio Taping w chorobach zapalnych układu ruchu u dzieci. Reumatologia/Rheumatology. 2009;46:340-7.

23. B. Imboden J., B. Hellmann D. HSJ. Juvenile Idiopathic Arthritis | CURRENT Diagnosis \& Treatment: Rheumatology,. In: Current Diagnosis \& Treatment: Rheumatology. 2007. https://accessmedicine. mhmedical.com/content.aspx ?bookid=506\&sectionid=42584904. Accessed 27 Apr 2021.

24. Ravelli A, Lattanzi B, Consolaro A, Martini A. Glucocorticoids in paediatric rheumatology. Clin Exp Rheumatol. 2011;29 5 SUPPL. 68.

25. B H, G H. The role of synthetic drugs in the biologic era: therapeutic strategies for treating juvenile idiopathic arthritis. Expert Opin Pharmacother. 2016;17:703-14. doi:10.1517/14656566.2016.1133592.

26. K W, LR W. Advances in the treatment of polyarticular juvenile idiopathic arthritis. Curr Opin Rheumatol. 2015;27:505-10. doi:10.1097/BOR.0000000000000206. 